\title{
AC 2009-1900: STUDENT ACADEMIC ADVISEMENT: INNOVATIVE TOOLS FOR IMPROVING MINORITY STUDENT ATTRACTION, RETENTION, AND GRADUATION
}

Stephen Crown, University of Texas, Pan American

Arturo Fuentes, University of Texas, Pan American

Constantine Tarawneh, University of Texas, Pan American

Robert Freeman, University of Texas, Pan American

Hashim Mahdi, University of Texas, Pan American 


\title{
Student Academic Advisement: Innovative Tools for Improving Minority Student Attraction, Retention, and Graduation
}

\begin{abstract}
Like most engineering programs across the country, the undergraduate mechanical engineering program at The University of Texas - Pan American, is engaged in the implementation of a process of continuous quality improvement that promotes students' academic and professional success and supports program and institution accreditations. In general, engineering, computing and applied science programs seeking accreditation by ABET (Accreditation Board of Engineering and Technology) must demonstrate, among other things, that they evaluate student performance, advise students regarding curricular and career matters, and monitor student's progress to foster their success in achieving program outcomes, thereby enabling them as graduates to attain program objectives. The paper describes innovative tools that support the advisement process and their impact on faculty and students. One effective tool has been an online degree planning software used by students and faculty. These tools have been successfully implemented in different programs in the same minority serving institution. The use of these tools has allowed the faculty to concentrate on other important aspects of the student academic advisement. This paper will also describe in detail the use of these tools in a comprehensive academic advisement process and its impact at an engineering program serving mainly minority students. The mandatory academic advisement has positively impacted student access, retention, and graduation. Students meet at least once a semester with an assigned engineering faculty member. Faculty monitor and advise students in areas such as proposed course workload and reasonable progress towards graduation, evaluation of grades, course prerequisites, graduation requirements, transfer/CLEP credits, university requirements, and early warnings. Faculty mentor students in areas and activities such as professional opportunities for students, answer questions about career choices, encourage good habits, building a relationship, financial aid/scholarships, and selection of technical electives appropriate to student interest and career goals. Furthermore, faculty help students find information about required courses, course prerequisites, course offerings at the University and other places, transfer credits / CLEP tests, consequences of repeating courses, answer questions about courses, and scholarships.
\end{abstract}

\section{Introduction}

Like most engineering programs across the country, the undergraduate mechanical engineering program (B.S.M.E.)at The University of Texas - Pan American (UTPA), is engaged in the implementation of a process of continuous quality improvement that promotes students' academic and professional success and supports program and institution accreditations. Based on this premise, student academic advisement has been a priority for the UTPA ME faculty since the beginning of the B.S.M.E. program. In general, engineering, computing and applied science programs seeking accreditation by ABET (Accreditation Board of Engineering and Technology) must demonstrate, among other things, that they evaluate student performance, advise students regarding curricular and career matters, and monitor student's progress to foster their success in achieving program outcomes, thereby enabling them as graduates to attain program objectives ${ }^{1}$. Even though the ABET criteria is continuously evolving and depends on the type of program, the 
ABET requirement for programs to document and improve the process by which students are advised has remained unchanged in the last revision cycles. Furthermore, different aspects of academic advisement and their relation with student retention and academic success have been reported in the literature ${ }^{2-5}$. These studies show evidence that student academic advisement is an important tool to retain traditionally underrepresented groups and students that may be classified as at risk students.

UTPA, a 78-year old, general academic component of the University of Texas System, is a comprehensive university serving more than 17,500 students annually of which over $85 \%$ are of Hispanic origin and are primarily commuter students. UTPA is a university that serves a unique region that has modest economic resources. The university student body is drawn primarily from the four county area of the lower Rio Grande valley (Starr, Hidalgo, Cameron, and Willacy Counties). The UTPA undergraduate Engineering programs including the B.S.M.E. program officially started in fall 1992. The B.S.M.E. program at UTPA has been growing in the past several years at the rate of approximately 8\%. In fall 2008, the Mechanical Engineering undergraduate student population (82.3\% Hispanic) was composed of approximately 500 students (17\% female). A significant fraction of the students are transfers from a local two-year institution. A significant number of students work while in college and/or are first generation college students. Even though recent reforms in the Texas public schools have resulted in more incoming students having some advanced placement credit in math or science classes, incoming student skills vary widely with a substantial number of students beginning mathematics in precalculus courses. Given these challenges, the need for a strong but cost effective student academic advisement and monitoring process has been recognized and addressed.

The authors, among other ME faculty members, have spent a significant number of hours refining the ME student advising and monitoring system. The ME faculty believe academic advising is a collaborative process between faculty and students to meet the essential learning outcomes. The ME faculty's role is to help students find the information, self-knowledge, and experiences that will move their life in the directions of their choice. Curricular and extracurricular experiences are integral to career and academic development, and ME faculty encourage students to seek opportunities both inside and outside the classroom. All the procedures for the advising and monitoring of students have been designed to ensure that students have every opportunity to be successful. All of the ME faculty have an active role in the evaluation, advisement, and monitoring of students in the program. In fall 2008, there were $14 \mathrm{Ph} . \mathrm{D}$. Engineering faculty members in the Mechanical Engineering department. Furthermore, the faculty of the program have been heavily involved from its inception in activities designed to raise awareness of engineering as a career, of UTPA as a good program for local students, and of the requirements and prerequisites for entry into a university engineering program. Because most potential students do not come from families or communities with engineers as role models, these activities are a crucial part of attracting interested and prepared students. Departmental outreach activities have included support for the TexPrep program, Upward Bound Mathematics and Science program, Gear-Up engineering camps, MathCounts competitions, college night and career day activities, National Engineering week programs, and numerous laboratory tours and demonstrations. 
The authors have also spent a significant number of hours developing and refining ME student advising and monitoring tools. While it was critical that the student academic advisement positively impacted student academic success including student retention and 5-year graduation rates, it was also important to facilitate the process for students and faculty and limit the cost or negative impact on faculty and supporting staff. The authors were also interested in facilitating that the student academic advisement process addressed not only student academic success but also student professional success. It was also recognized that there is an opportunity to link advisement and strategic planning including the planning of future course offerings and course additions. The advising of students and scheduling of courses work toward the goal that students can graduate in a timely fashion. The following sections describe the UTPA B.S.M.E. student advising process, including student advising objectives, the developed student academic advisement tools, and the impact of the advising process and the innovative tools on students and faculty.

\section{Student Advising Process}

The student academic advisement process in the ME program at UTPA is part of a departmental continuous quality improvement process that also addresses specific ABET accreditation concerns. The student advising process was reviewed in detail by the ME faculty during the academic year 2005-2006. Advising objectives were defined to make sure that students and faculty have clear expectations of this important process. The student advising objectives are:

1) ME Faculty will monitor and advise students in areas such as proposed course workload/ reasonable progress towards graduation, evaluation of grades, course prerequisites, graduation requirements, transfer/CLEP credits, university requirements, and early warnings.

2) ME Faculty will mentor students in areas and activities such as professional opportunities for students (internships, professional societies, co-ops, undergraduate student research and industry projects, design competitions, professional meetings, etc.), answer questions about career choices, encourage good habits (study habits, ethical behavior, healthy life, stress management techniques, search for any required professional help, etc), motivation (rewards of hard work, celebrate success, learn from failure, etc.), building a relationship (personal accountability, showing that we care, etc.), financial aid/scholarships, and selection of technical electives appropriate to student interest and career goals

3) ME Faculty will help students find information about required courses, course prerequisites, course offerings at UTPA and other places, transfer credits / CLEP tests, consequences of repeating courses, answer questions about courses, and scholarships.

Figure 1 summarizes the UTPA B.S.M.E. Student Advising Objectives. 


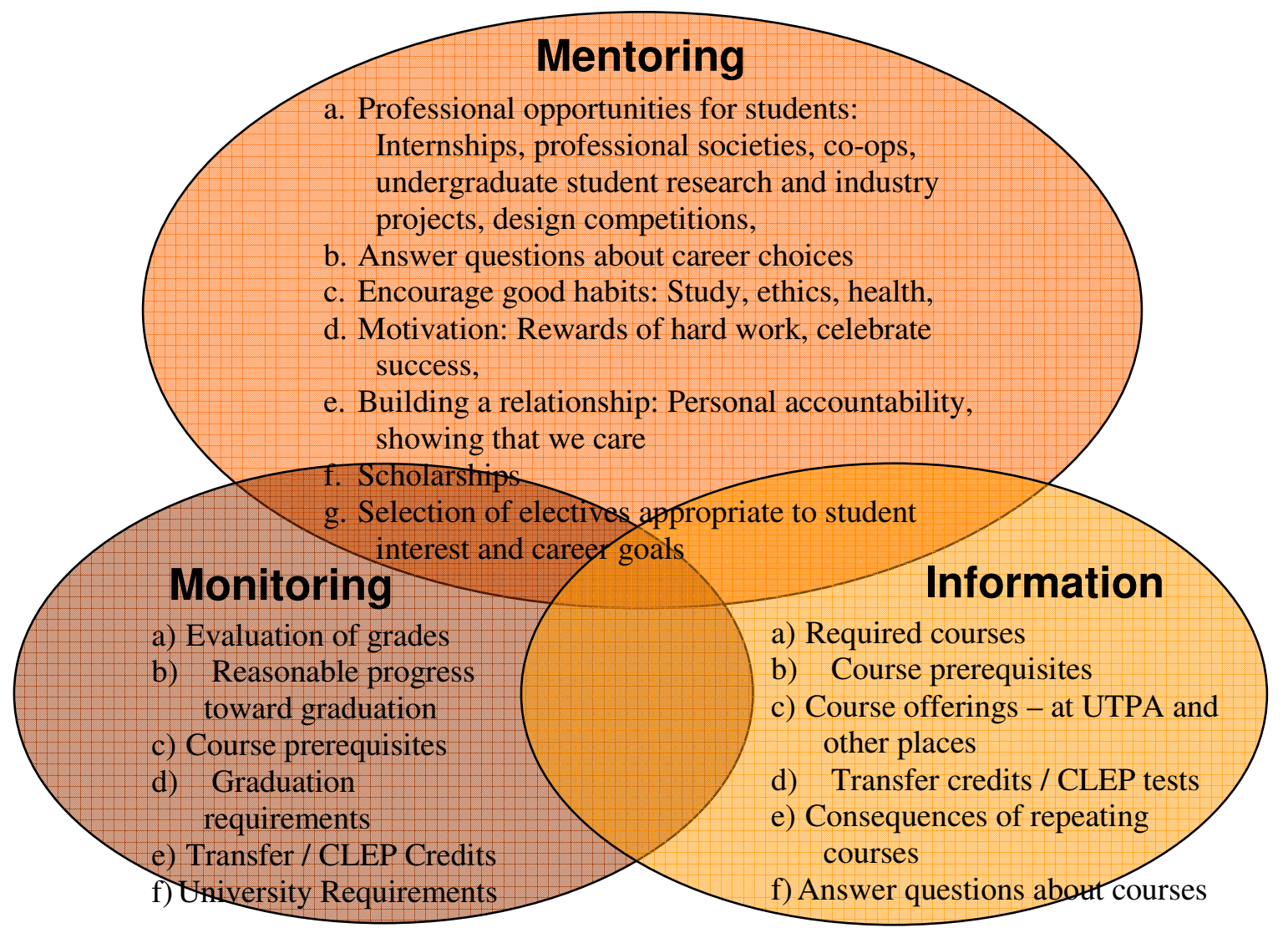

Figure 1. $\quad$ UTPA B.S.M.E. Student Advising Objectives

The Office of Admissions and Records, with input form the engineering faculty, has worked and implemented an automated pre-requisite checking plan. However, the primary responsibility for academic advising is given to ME faculty members. Each appointed ME faculty member is assigned a group of students based on the last digit of their student identification number. While ME faculty members are available for student advising informally throughout the year, two weeks prior to the beginning of the student registration period are formally dedicated for this purpose. The faculty members' time investment for student academic advisement has usually been between 10 to 15 hours per semester. As an example, in fall 2008 the Mechanical Engineering undergraduate student population was composed of approximately 500 students and there were 11 out of $14 \mathrm{Ph} . \mathrm{D}$. ME faculty members who were appointed for student advising. First year ME faculty members are not appointed for student advising. Each appointed ME faculty member accommodated around 50 advisement slots (12.5 hours) throughout the two weeks of advisement period. It is important to mention that the merit document of the Mechanical Engineering department support student academic advisement by considering this activity as valuable service to the department.

Figure 2 shows the advising procedure instructions given to the UTPA B.S.M.E faculty. 


\section{Academic Advising Procedure (from Faculty Handbook)}

a. The Department of Mechanical Engineering requires mandatory advising where students meet with the assigned faculty as shown on the advising poster. Advising assignments are made by the last digit of the student's ID number. All ME faculty members encourage students to be advised by their assigned faculty advisor, by whom they are advised throughout their enrollment.

b. Students must make appointments to meet with their advisors during the advisement period. Faculty members will use student advising appointment signup website or post an advisement signup sheet on their office door throughout the first two weeks of advisement with a minimum of 50 advisement slots (12.5 hours).

c. Students must complete and save the advising worksheet before coming for advising. The tutorial movie should answer their basic questions.

\section{http://crown.panam.edu/advising/index.html}

d. Students that need a co or prerequisite waiver should request a letter from the Department Chair or the U.G. program director who will approve the request with input from the appropriate faculty member(s). Only under exceptional circumstances will a pre-requisite waiver be granted. Faculty members are encouraged to take advantage of the advisement meeting with the student to accomplish the rest of the student advising objectives (monitoring, mentoring, and information). The advising information form promotes discussion about student concerns and helps the advisor monitor student performance, progress, and study habits. Additionally, the questions below may help faculty to break the ice.

Question 1. Have you thought about what you want to do when you graduate?

Question 2. When do you expect to graduate?

Question 3. Do you know why it is important to plan out several semesters in advance in the advising spread sheet? (Answer: The data is going to a database to help the ME Department schedule necessary courses for students and balance ME faculty teaching load.)

e. During the advisement meeting, the faculty member and student review the student advising worksheet. The faculty member saves the approved degree plan with the advisor password on the website: http://crown.panam.edu/advising/index.html

f. Provide feedback about the advising process to Dr. Crown, Dr. Freeman, or Dr. Fuentes after the advisement period for continuous quality improvement. Please keep track of student frequently asked questions and interests and any other information that may be useful to include in the faculty handbook.

Figure 2 UTPA B.S.M.E. Student Academic Advising Instructions 


\section{Advisement Tools}

The advising documentation is updated annually and is posted on the ME Student Advising page (http://www.crown.panam.edu/advising), Department Web page, Faculty Handbook, and ME Department Bulleting board. The information posted includes precise instructions to make an appointment, registration, course selection, and information on the selection of elective credits. Figure 3 shows the B.S.M.E. student advising website. The information on the website prepares the student for their advising appointment by addressing common advising issues allowing more time for interaction on individual advising issues. The student advising page includes three main links to an advising information form, course planning spreadsheet, and appointment scheduler. The advising information form documents student advising questions and their current weekly schedules. The course planning spreadsheet helps the student select appropriate courses for the upcoming and future semesters. Finally, the appointment scheduler allows the student to schedule an advising appointment online.

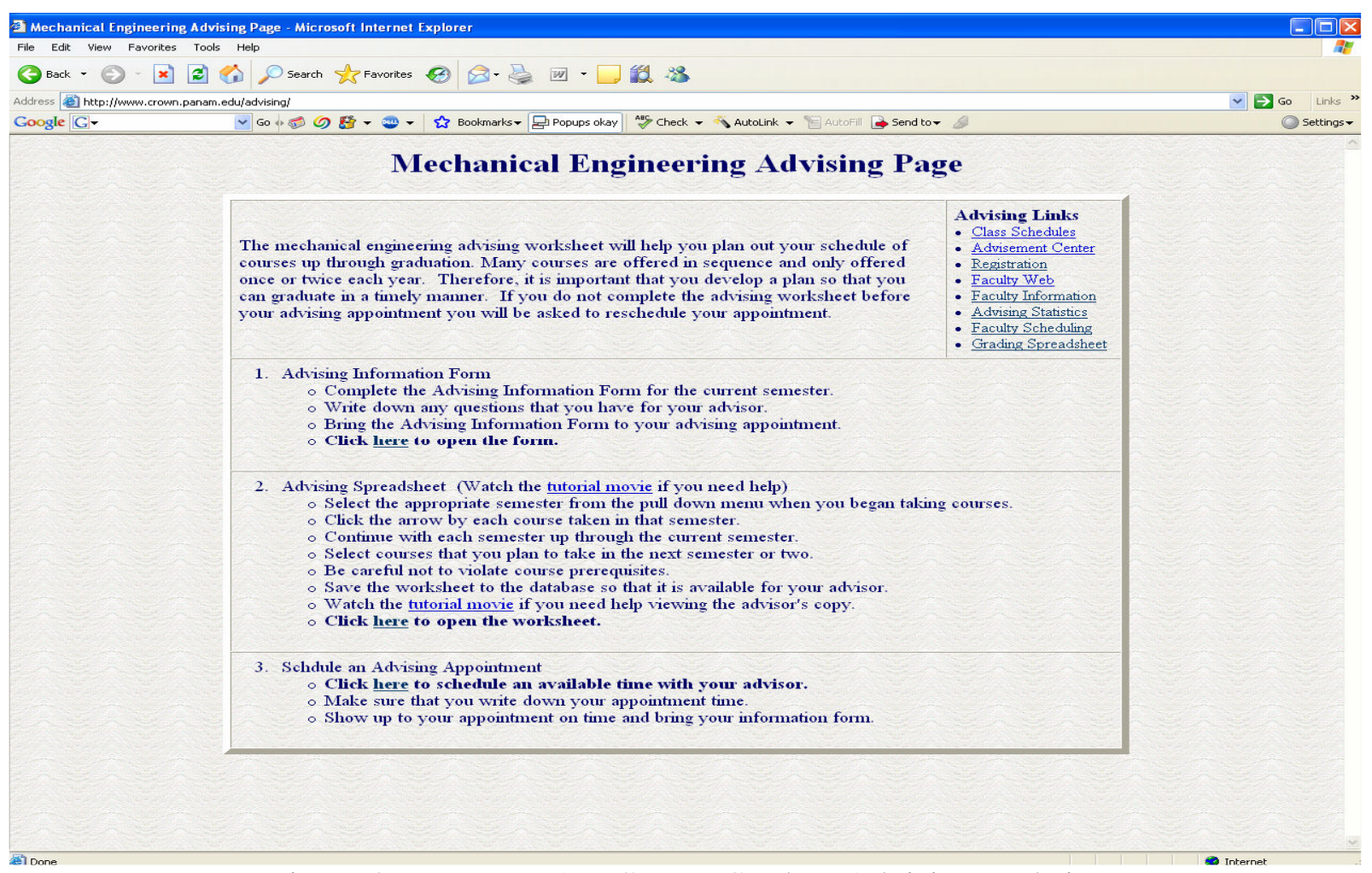

Figure 3. $\quad$ UTPA B.S.M.E. Student Advising Website

Students who come in unprepared for an advising appointment are often focused on their immediate need and ask "What courses should I take next semester?" The advising information form, shown in Figure 4, encourages students to be more reflective about their educational plan and to use the advising time with a faculty member to refine that plan. Much of the form focuses on the current semester and has the student document how their time is spent during a typical week including class and study hours, work schedules, and other regular commitments. The form encourages students to block out 3-4 hours per week per semester credit hour in their weekly schedule. During the advising time the faculty can make practical suggestions about 
time management for the current semester and help the student make adjustments in course load or reducing outside commitments for the upcoming semester. The form also encourages students to write down questions about their longer term vision such as their area of interest within the discipline, internships, and future career plans. A frequently asked questions link addresses many of the common questions that students ask freeing the advising time for greater personal interaction about plans and goals.

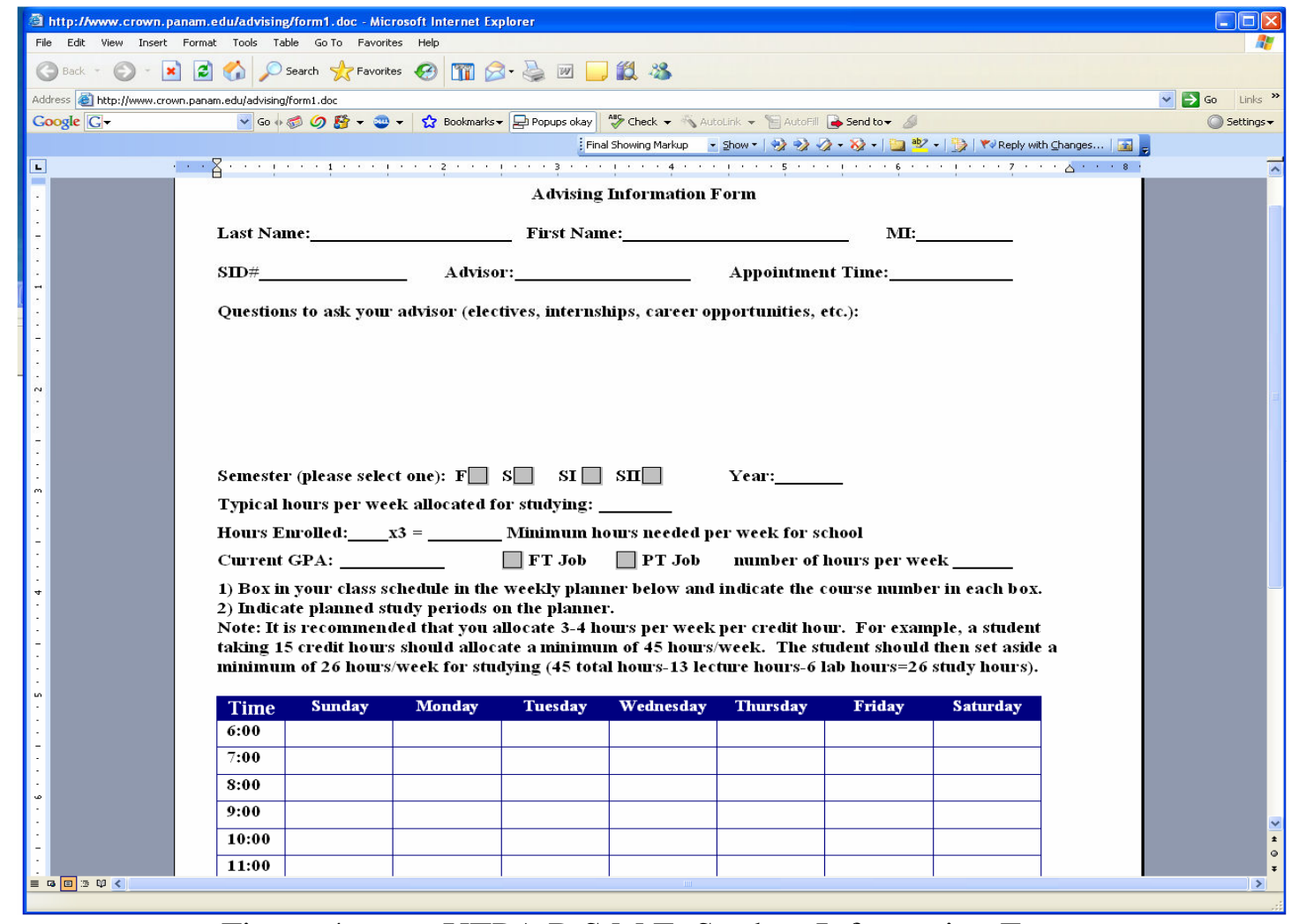

Figure 4. UTPA B.S.M.E. Student Information Form

The student's historical record of advising information forms show the advisor how the student's time management skills have possibly matured over time and reminds the advisor of student's ongoing questions. Currently the form is submitted at the time of the appointment. However, the questions portion of the form will soon be linked to the student database so that advisors can preview questions before the advising appointment. The collective data from all student advising information forms can be used to update the frequently asked questions page. Linking these two resources will allow the students to have immediate answers for many of their questions and alert their advisor of specific unanswered questions.

The degree plan for engineering programs is made up of many interrelated courses that build in complexity as students progress through the program. Many upper division courses depend heavily on the students understanding of math, physics, chemistry, programming, and other fundamental courses. Many upper division engineering courses depend on the completion of as many as five or six foundational courses. Although engineering program degree plans are typically listed in a semester by semester suggested sequence many factors cause students to break out of this plan. Among those factors are varying math placement scores and high school 
transcripts, closed course sections, transfer credits, different work schedules, and repeated courses. It can be challenging to students and sometimes for the advisor to determine what courses the student can take and should take that balances best with their schedule and that leads to the shortest time to graduation. The course planning spreadsheet, shown in Figure 5, gives the student a tool that clearly shows what courses they are prepared to take for the upcoming semester and subsequent semesters up through graduation.

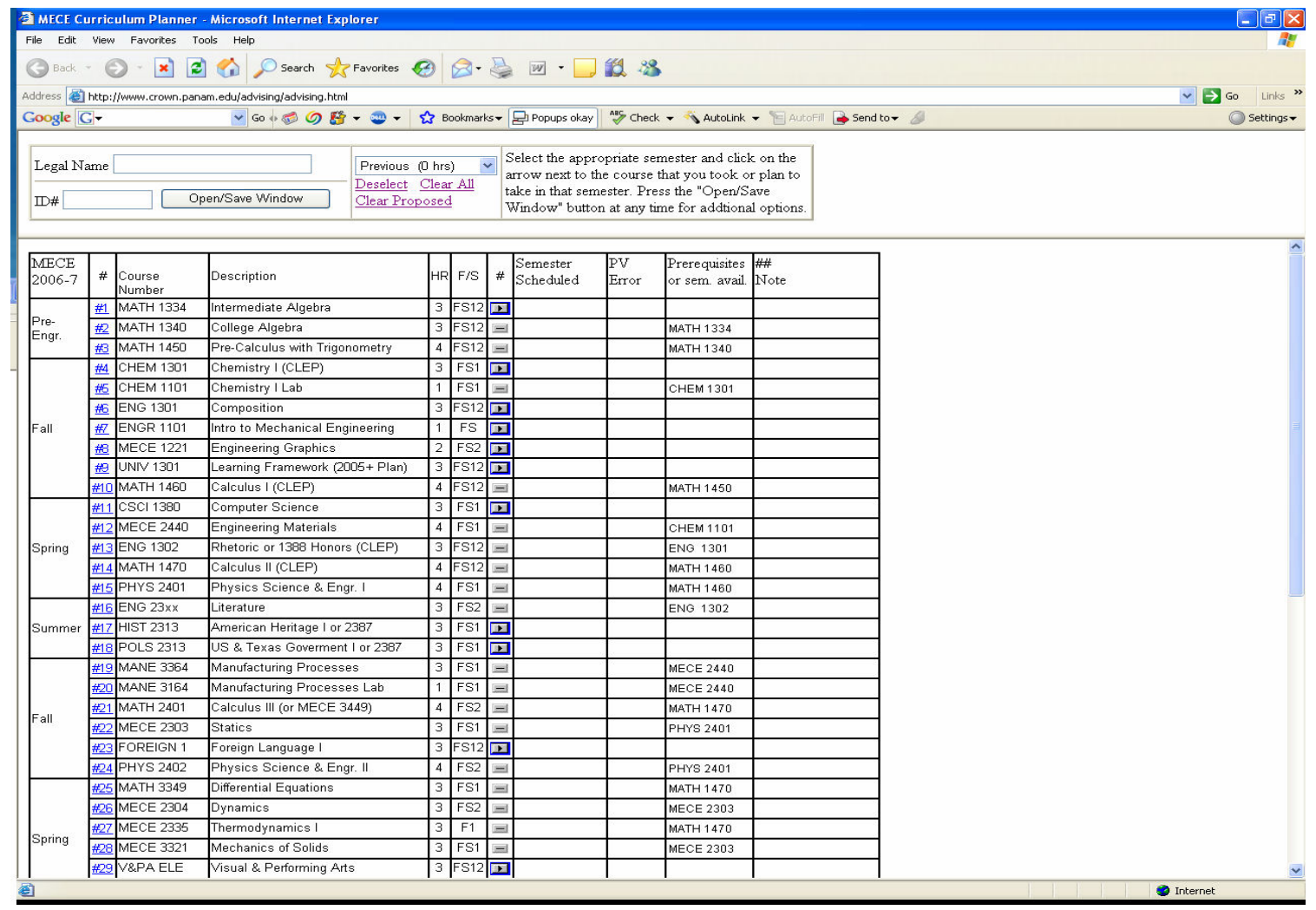

Figure 5.

Online B.S.M.E. Student Advising Worksheet

To use the advising tool students simply enter the semester that they have taken each course listed in the degree plan. The program checks all course prerequisites in the degree plan and indicates which courses have all prerequisites fulfilled for upcoming semesters. The student can select from that list of courses for the upcoming semester which opens up a new list of available courses for the following semester. In the span of less than thirty minutes the student can plan out their schedule through graduation. The students plan is saved to a database that can be retrieved through the internet and viewed on the advising webpage. At the time of the advising appointment the advisor reviews the students plan, discusses concerns, makes any necessary changes, and saves the approved plan. This process, which prior to use of the spreadsheet occupied all of the advising time, typically takes less than five minutes. Additionally, course selection through graduation was not typically considered until the end of the junior year causing scheduling difficulties for some students.

The database generated by the student advising process has helped with other advising and departmental functions. The database can be easily accessed to provide detailed information 
about course enrollment for several semesters in advance. As an example of the usefulness, expected course enrollment for a service course which was dropped from the new degree plan was verified through the database and a list of students who had planned on taking the course was provided to the department. Having justification that the course would be filled, the closed section was offered. Expected enrollment, with actual class rolls, for courses in upcoming semesters helps to plan for needed summer course offerings, elective courses, and opening new sections of courses. With the offering of over 20 electives (advanced professional preparation courses), it is beneficial to have student course offering preferences several semesters in advance. Figure 6 shows the tentative schedule for the advanced professional preparation courses. The online database also allows for record keeping of the advising process, the ability for students to be advised by another advisor, and the occasional advising of students in coops via the internet.

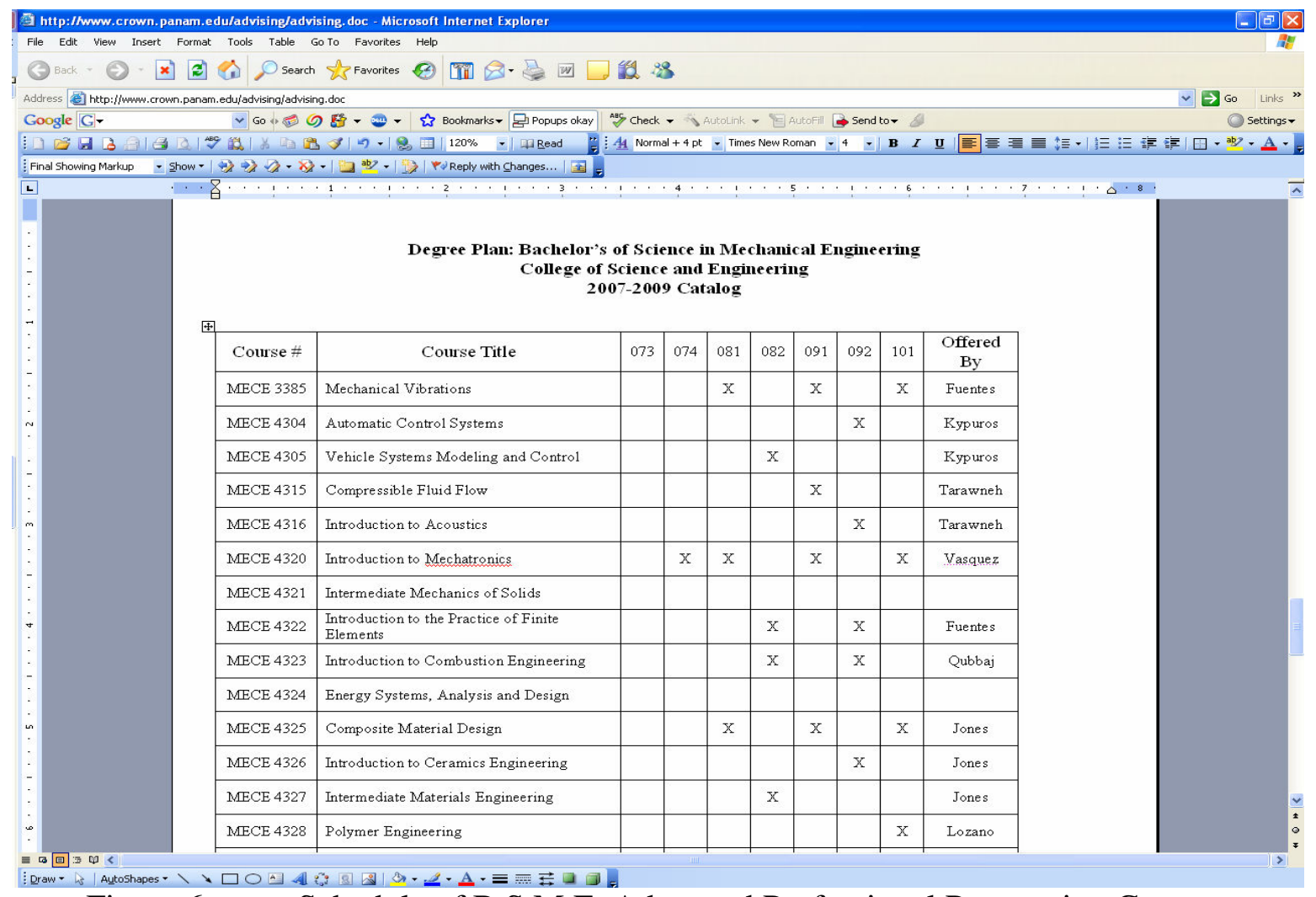

Figure 6. $\quad$ Schedule of B.S.M.E. Advanced Professional Preparation Courses

Recently, an online appointment scheduler and calendar, shown in Figure 7, was added to the system. Prior to this system students signed up for an appointment on the faculty member's door. The online appointment scheduler allows the faculty member to check their appointment schedule remotely and make any necessary changes in their availability as they schedule other commitments. Students can easily reschedule their appointment opening up a time for another student and alerting the faculty member of the change. The system has increased the accessibility of students to their advisor while making the advising period less restrictive for the faculty member. The appointment scheduler also sends the student a reminder of the scheduled appointment and the faculty member a calendar event via their email if they desire. 


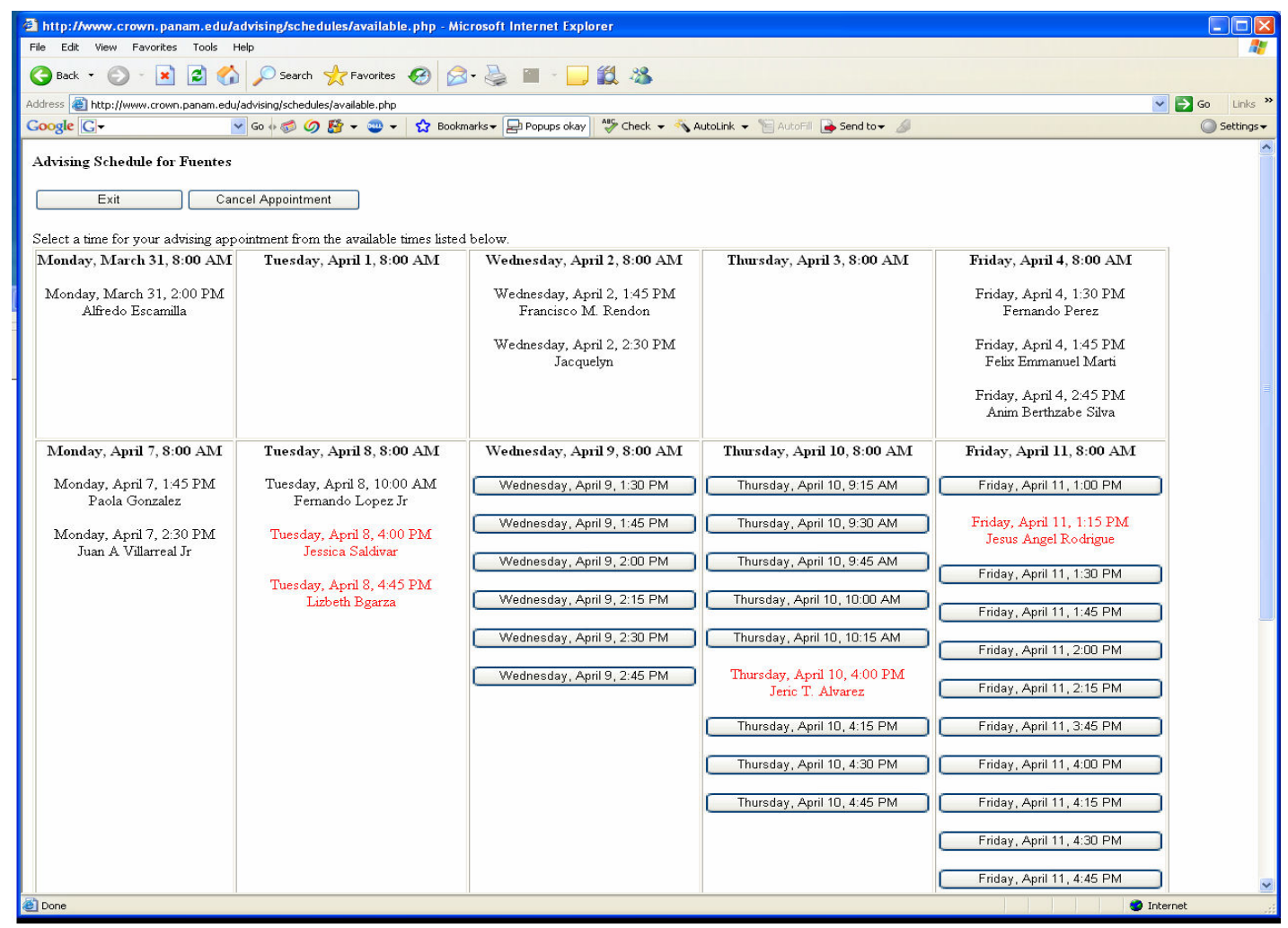

Figure 7.

B.S.M.E. Student Advising Appointment Signup Website

The online advising resources were developed by the authors and used successfully within the mechanical engineering program for several years. The system was developed so that it is easily adaptable to other degree plans and has been set up for use with the manufacturing and electrical engineering programs. Recently, the system was adopted by another undergraduate and graduate program within the university outside of engineering.

\section{Impact on Students and Faculty}

There have been significant improvements in the B.S.M.E. program student time to graduation. The typical B.S.M.E. student takes 5 years to graduate. During the last ABET visit, the typical student took around 5.5 years to graduate ( $10 \%$ more than current time to graduation). The B.S.M.E. program four year and five year graduation rates are significantly higher (up to $37 \%$ higher) than the corresponding rates from the overall School of Engineering and Computer Science and UTPA. The B.S.M.E. program student retention continues to compare favorably to the School of Engineering and the University rates despite a much greater relative increase in the B.S.M.E. program enrollment. The average GPA of the B.S.M.E. program graduates is 3.0. The typical trend in the student GPA is that the freshman students have the lowest GPA and that students significantly improve their GPA by the time of graduation. These positive trends in graduation rates are the result of different activities and initiatives including the refined advisement process and innovative advisement tools, additional course offerings, and of the faculty cohesiveness. Even tough there is a significant faculty time investment, so far faculty members have not expressed major negative concerns but have expressed that the advising procedure is easier with the use of the online advisement tools. 
The ME program, through the Career Placement office and ME faculty advising, has been highly successful in placing the graduates in industry (permanent employment, internship, or cooperative education) and graduate school. A high percentage of B.S.M.E. students hold at least one summer engineering internship before graduation. B.S.M.E. graduates have been placed in permanent jobs with Fortune 500 companies and research laboratories including Lockheed-Martin, Boeing, Raytheon, Ford, Toyota, General Motors, Peterbilt, Proctor and Gamble, General Electric, Schlumberger, Halliburton, Johnson Controls, Motorolla, Cummins, Technip USA, and Southwest Research Institute. Furthermore, several of our engineering B.S.M.E. graduates have been accepted into graduate school at well-known institutions including Northwestern University, Stanford, U.T. Austin, Texas A\&M, and Rice University.

The advising procedure and online advisement tools have been recently adopted by the Global Security Studies and Leadership (GSSL) program at UTPA for their graduate and undergraduate advising. The GSSL program, a relatively new program, has been positively impressed with the results they have observed so far.

\section{Conclusion}

The student academic advisement process developed for and implemented in the ME program at UTPA is part of a departmental continuous quality improvement process that also addresses specific ABET accreditation concerns. In agreement with the literature, the mandatory academic advisement process has positively impacted student access, retention, and graduation rates for a challenging student population that is comprised of many first generation college students and who are employed full time. The development and use of online advisement tools has improved both the quality and efficiency of the advisement process better preparing students for academic success and reducing the negative impact on faculty and supporting staff. Furthermore, while the developed electronic degree plan serves to assure that all students meet all program requirements, it also serves as an important planning tool that allows us to quantitatively understand and control student academic progress through, among other things, timely course offerings. These tools have been successfully implemented in a number of different programs in the same Minority serving institution.

\section{Bibliography}

1. http://www.abet.org/

2. Walser, A. D.; Alting, A.; Baurin, E.; “Academic advisement tool for retaining underrepresented engineering students", ASEE Annual Conference and Exposition, Conference Proceedings, 2005 ASEE Annual Conference and Exposition, Conference Proceedings, 2005, p 99-105

3. Alting, A.; Golovatch, E.; Macauley, N.; Walser, A. D.; "The use of requisite check as an academic and curriculum advisement tool in retaining underrepresented engineering students", ASEE Annual Conference Proceedings, 2003 ASEE Annual Conference and Exposition: Staying in Tune with Engineering Education, 2003, p 9199-9207The biliography must be in Time New Roman, 10 point.

4. Ogunfunmi, T.; "Minority graduate student advising and mentoring for career advancement", ASEE Annual Conference and Exposition, Conference Proceedings, 2007 ASEE Annual Conference and Exposition, 2007, 8p

5. Baxter, K.; Yates, L.; "Addressing freshmen retention through focused advisement and seminar programs", ASEE Annual Conference and Exposition, Conference Proceedings, 2008 ASEE Annual Conference and Exposition, 2008, 9p 